\title{
Factors influencing the contraceptive method choice: a university hospital experience
}

\section{Kontraseptif yöntem seçimini etkileyen faktörler: Bir üniversite hastanesi deneyimi}

\author{
Korhan Kahraman', Göksu Göçl, Salih Taşkın', Pınar Haznedar², Selen Karagözlü², Burak Kale², Zeynep Kurtipek², \\ Batuhan Özmen ${ }^{1}$ \\ ${ }^{1}$ Department of Gynecology and Obstetrics, Faculty of Medicine, Ankara University, Ankara, Turkey \\ ${ }^{2}$ Faculty of Medicine, Ankara University, Ankara, Turkey
}

\section{Abstract}

Objective: To analyze the factors influencing behavior of women in choosing contraceptive methods.

Material and Methods: A total of 4022 women who were admitted to our clinic in a year, were the subjects in this current study for contraception choices. Relationship between the current contraceptive choice and the age, marital status, educational level, gravidity and induced abortions were evaluated.

Results: Current users of any contraceptive methods were found to make up thirty-three percent of the entire study population. The most preferred method of contraception was an intrauterine device (46.4\%), followed by, condom (19.2\%), coitus interruptus (16.4\%), tubal sterilization (11\%), oral contraceptives (5.7\%) and lastly the "other methods" that consisted of depot injectables and implants (1.2\%). Among other contraceptive methods, the condom was found to be used mostly by the younger age group (OR:0.956, 95\% CI:0.936-0.976, p<0.001), while tubal sterilization was preferred mainly by the elderly population ( $\mathrm{p}<0.001$, OR:1.091, 95\% CI:1.062-1.122). Women that have a higher educational level, were found to use OC (76.3\%, OR:5.970, 95\% CI:3.23311.022), tubal sterilization (59.6\%, OR:4.110, 95\% CI:2.694-6.271) and other methods (62.5\%, OR:3.279, 95\% CI:1.033-10.402) more commonly than the low educational group $(\mathrm{p}<0.001)$.

Conclusion: These results demonstrated that the rates of both contraception utilization and the usage of more effective methods of contraception need to be increased by providing better family planning systems and counselling opportunities.

(J Turkish-German Gynecol Assoc 2012; 13: 102-5)

Key words: Contraceptives, method choice, demographic factors, intrauterine device

Received: 24 October, 2011

Accepted: 19 January, 2012

\section{Özet}

Amaç: Kontraseptif yöntem seçimini etkileyen faktörlerin analizi.

Gereç ve Yöntemler: Bir ylllık süre içerisinde kliniğimize başvuran 4022 olgunun, kontraseptif yöntem seçimleri incelendi. Mevcut kontraseptif seçimleri ve yaş, medeni hal, eğitim seviyesi, gebelik, kürtaj durumları arasındaki ilişki değerlendirildi.

Bulgular: Kontraseptif yöntem kullanan olgular, çalışma popülasyonunun \%33'ünü oluşturmaktadır. En çok tercih edilen yöntem rahim içi araç (\%46.4) iken, diğer yöntemler sırasıyla; kondom \%19.2, geri çekme \%16.4, tubal sterilizasyon \%11, oral kontraseptifler \%5.7, depo enjeksiyonlar ve implantlar \%1.2 oranında kullanılmaktadırlar. Kondom diğer metotlara göre daha genç yaş grubunda tercih edilmekte iken (OR:0.956, \%95 CI:0.936-0.976, p<0.001), tubal sterilizasyonun daha ileri yaş olgular tarafından tercih edildiği saptandı $(\mathrm{p}<0.001$, OR:1.091, \%95 CI:1.062-1.122). Eğitim seviyeleri, oral kontraseptif (\%76.3, OR:5.970, \%95 CI:3.233-11.022), tubal sterilizasyon (\%59.6, OR:4.110, \%95 CI:2.694-6.271), depo enjeksiyon ve implant (\%62.5, OR:3.279, \%95 CI:1.033-10.402) kullanıcılarında diğer gruplara göre anlamlı oranda yüksek saptandı $(\mathrm{p}<0.001)$.

Sonuçlar: Bu sonuçlar daha iyi bir aile planlaması sistemi ve danışmanlığı ile hem kontrasepsiyon oranının artırılması hem de daha etkin yöntemlerin kullanımının yaygınlaştırılması gerektiğini göstermektedir. (J Turkish-German Gynecol Assoc 2012; 13: 102-5)

Anahtar kelimeler: Kontraseptifler, metot seçimi, demografik faktörler, rahim içi araç

Geliş Tarihi: 24 Ekim 2011

Kabul Tarihi: 19 Ocak 2012

\section{Introduction}

Aproximately half a million women die around the world each year, as a result of pregnancy and associated complications. Most of these deaths could be prevented, not only by providing immediate and appropriate medical care, but also by offering family planning counseling and services, which could prevent many future unintended high-risk pregnancies and unsafe induced abortions (1). Contraception methods can prevent at least $25 \%$ of all maternal deaths by allowing women to prevent unintended pregnancies and unsafe abortions, and to protect themselves from sexually transmitted diseases including HIV (2). Demographic characteristics, cultural and religious beliefs, and economic and education levels of the female pop- 
ulation can also affect the selection of a contraceptive method (3). In this population-based study, we aimed to compare the factors that influence the choice of contraception.

\section{Material and Method}

A total of 4022 women admitted to the University hospital in the period of a year (March 2010-May 2011), were evaluated for contraceptive method preference. All of the sexually active women aged between 15-49 were included in this cross-sectional study. Relationship between the current contraceptive choice and the age, marital status, educational level, gravidity and induced abortions were evaluated. Major contraceptive methods in this study were oral contraceptives (OCs), intrauterine devices (IUDs), coitus interruptus (CI), male condom, tubal sterilization (TS). Depot injection agents and implants were grouped as other (miscellaneous). The results were evaluated with Kruskal Wallis, Chi-square and multinomial logistic regression statistical methods in SPSS 15 and $p$ value $<0.05$ was accepted as statistically significant.

\section{Results}

Thirty-three percent of the patients (1327/4022) were currently using contraceptive methods. The mean age of women using contraception was 32.3 years (range 15-49). Demographic characteristics, marital status, educational level and the rate of contraception utilization of subjects were demonstrated in Table 1. The most preferred method of contraception was intrauterine device $(46.4 \%)$, followed by other preferred methods, condom (19.2\%), coitus interruptus (16.4\%), tubal sterilization (11\%), oral contraceptives (5.7\%) and lastly the

Table 1. Demographic characteristics and percentage distribution of women using contraceptive methods $(n=1327)$

\begin{tabular}{|c|c|c|c|c|c|c|c|}
\hline $\begin{array}{l}\text { Sociodemographic } \\
\text { characteristics }\end{array}$ & IUD (\%) & Condom (\%) & CI (\%) & TS (\%) & OCD (\%) & Other (\%) & Non-use (\%) \\
\hline \multicolumn{8}{|l|}{ Age (yrs) } \\
\hline$<20$ & $13(2.1)$ & $13(5.1)$ & $5(2.3)$ & - & $3(4)$ & - & $123(4.5)$ \\
\hline $20-29$ & $18(30.0)$ & $97(3.0)$ & $67(30.7)$ & 20 (13.8) & $24(31.6)$ & $5(31.3)$ & $348(12.9)$ \\
\hline $30-39$ & $227(36.9)$ & 85 (33.3) & 73 (33.5) & $64(43.8)$ & 30 (39.5) & $8(50.0)$ & $1304(48.4)$ \\
\hline$>40$ & $191(31.0)$ & $60(23.6)$ & 73 (33.5) & $62(42.4)$ & 19 (25.0) & $3(18.7)$ & $920(34.2)$ \\
\hline \multicolumn{8}{|l|}{ Gravida } \\
\hline 0 & $56(9.1)$ & $76(29.8)$ & 30 (13.8) & - & $16(21.1)$ & $1(6.2)$ & $1211(44.9)$ \\
\hline 1 & $130(21.1)$ & $42(16.5)$ & 42 (19.3) & $10(6.7)$ & $14(18.4)$ & $4(25.0)$ & 867 (32.2) \\
\hline 2 & $150(24.4)$ & $52(20.3)$ & $51(23.4)$ & 27 (18.7) & 19 (25.0) & $3(18.8)$ & $427(15.9)$ \\
\hline$\geq 3$ & $280(45.5)$ & 85 (33.3) & 95 (43.6) & $109(74.6)$ & 27 (35.5) & $8(50.0)$ & $190(7.0)$ \\
\hline \multicolumn{8}{|l|}{ Parity } \\
\hline 0 & $66(10.7)$ & $81(31.8)$ & $31(14.2)$ & - & 18 (23.7) & $1(6.4)$ & $1582(58.7)$ \\
\hline 1 & $172(27.9)$ & $53(20.8)$ & $53(24.3)$ & $15(10.3)$ & 21 (27.6) & $5(31.2)$ & $919(34.1)$ \\
\hline 2 & $245(39.8)$ & 85 (33.3) & $92(42.2)$ & $59(40.4)$ & 27 (35.5) & $5(31.2)$ & $118(4.4)$ \\
\hline$\geq 3$ & $133(21.6)$ & $36(14.1)$ & 42 (19.3) & $72(49.3)$ & $10(13.2)$ & $5(31.2)$ & $76(2.8)$ \\
\hline \multicolumn{8}{|l|}{ Curettage } \\
\hline 0 & $431(70.0)$ & $199(78.0)$ & $162(74.3)$ & 79 (54.1) & 53 (69.7) & $10(62.5)$ & $814(30.2)$ \\
\hline 1 & $105(17.1)$ & 34 (13.4) & $31(14.3)$ & 34 (23.3) & $12(15.8)$ & $4(25.0)$ & $1154(42.8)$ \\
\hline 2 & $50(8.0)$ & $14(5.5)$ & $16(7.3)$ & 20 (13.6) & 10 (13.2) & $1(6.2)$ & $432(16.0)$ \\
\hline$\geq 3$ & $30(4.9)$ & $8(3.1)$ & $9(4.1)$ & $13(9.0)$ & $1(1.3)$ & $1(6.3)$ & $295(11.0)$ \\
\hline \multicolumn{8}{|l|}{ Marital Status } \\
\hline Married/Divorced & 589 (95.6) & $220(86.3)$ & 207 (95.0) & $146(100)$ & 68 (89.4) & $16(100)$ & $1844(68.4)$ \\
\hline Never married & $27(4.4)$ & 35 (13.7) & $11(5.0)$ & - & $8(10.6)$ & - & 851 (31.6) \\
\hline \multicolumn{8}{|l|}{ Educational Level } \\
\hline$\geq$ High school & $248(40.2)$ & 89 (34.9) & $96(44.0)$ & 87 (59.6) & $58(76.3)$ & $10(62.5)$ & $1218(45.2)$ \\
\hline$<$ High school & $368(59.8)$ & $166(65.1)$ & $122(56.0)$ & $59(40.4)$ & $18(23.7)$ & $6(37.5)$ & $1477(54.8)$ \\
\hline Total & 616 & 255 & 218 & 146 & 76 & 16 & 2695 \\
\hline
\end{tabular}


'other methods' that consist of depot injectables and implants (1.2\%) (Table 4).

Amongst women that utilize contraception, $62.7 \%$ were older than 30. Contraception usage rates were low and there is no case that underwent a tubal sterilization younger than 20 years of age, amongst the included women (Table 1). The intrauterine device is the most commonly used method. The mean age of IUD users was 34.5 ( \pm 8.0$)$ and $95.8 \%$ of this group consisted of femes covert or women that have had at least one previous marriage. Prevalence of IUD usage was highest amongst the women between the ages of $30-40(36.9 \%, n=227)$. A male condom was the most commonly used method amongst the women younger than 30 (43.1\%, OR:0.956, 95\% CI:0.936-0.976, $\mathrm{p}<0.001)$ and tubal sterilization was the least preferred option in this group (13.8\%). However the mean age of women preferring tubal sterilization as a contraceptive method, was 36.9 $( \pm 4.3)$ which was higher than other contraceptive methods $(p<0.001$, OR:1.091, 95\% CI:1.062-1.122). The mean values as regards to contraceptive methods are given in Table 2 .

Gravidity of included women were similar between all the groups and the majority of the women have had 3 or more previous pregnancies. In addition, nearly $90 \%$ of the sterilized women were found to have had more pregnancies and parities than 3 . The percentage of women that have had 3 or more elective abortions was found higher in the sterilized group (9\%).
Subjects were classified into two groups regarding their educational levels as including women to have at least a highschool degree, and including women that have less educational degree than highschool. In the comparison of these groups, women that have a higher educational level were found to use OC (76.3\%, OR:5.970, 95\% CI:3.233-11.022), tubal sterilization (59.6\%, OR:4.110, 95\% CI:2.694-6.271) and other methods (62.5\%, OR:3.279, 95\% CI:1.033-10.402) more commonly than the latter group $(\mathrm{p}<0.001)$. Rates of IUD and withdrawal method usage were similar between these two groups (40.3\%, 44\%). Relationship of contraceptive method choices with age and educational level are demonstrated in Table 3.

\section{Discussion}

The present study focused on the utilization and choice of contraception, and the change in preferred contraceptive method. Regarding the data obtained from the USA, approximately $62 \%$ of women between the ages pf 15 and 44 were currently using contraception in 2006-2008 (4) although this rate was found lower, as 33\%, in our study. Our results showed that almost 59\% of the women that do not use contraception were nulliparous and did not use any contraceptive method possibly owing to their wish for pregnancy (Table 1). This rate seems high compared to the literature (4-9).

Table 2. The clinical characteristics of women using contraceptive methods

\begin{tabular}{|c|c|c|c|c|c|c|c|}
\hline & CI & IUD & OCD & Condom & Tubal sterilization & Other & $* * \mathbf{p}$ \\
\hline Age, year * & $34.2(8.3)$ & $34.1(8.0)$ & $32.8(8.5)$ & $32.7(8.4)$ & $36.9(4.3)$ & $34.3(5.8)$ & $<0.05$ \\
\hline Gravidy * & $2.43(1.7)$ & $2.58(1.8)$ & $2.16(1.8)$ & $1.87(1.7)$ & $3.64(2.1)$ & $2.13(1.05)$ & $<0.05$ \\
\hline Parity * & $1.69(1.0)$ & $1.78(1.05)$ & $1.42(1.07)$ & $1.33(1.15)$ & $2.43(1.26)$ & $1.88(0.95)$ & $<0.05$ \\
\hline Curettage * & $0.42(0.8)$ & $0.52(1.02)$ & $0.52(1.02)$ & $0.34(0.74)$ & $0.86(1.28)$ & $0.56(0.89)$ & $<0.05$ \\
\hline Marital status (\%) & 94.9 & 95.8 & 89.4 & 86.2 & 100 & 94.7 & $<0.05$ \\
\hline Education (\%) & 44.1 & 40.3 & 76.0 & 34.9 & 59.4 & 60.3 & $<0.05$ \\
\hline
\end{tabular}

Table 3. Adjusted Odds Ratios from Multinomial Logistic regression

\begin{tabular}{|l|c|c|c|c|}
\hline \multicolumn{2}{|c|}{} & OR & $\begin{array}{c}\text { 95\% CI of OR } \\
\text { (Lower-Upper) }\end{array}$ & p \\
\hline \multirow{2}{*}{ OCP } & Age & 1.029 & $0.995-1.065$ & 0.099 \\
\cline { 2 - 5 } & Educational Status & 5.970 & $3.233-11.022$ & $<0.001$ \\
\hline \multirow{2}{*}{ CI } & Age & 1.007 & $0.985-1.030$ & 0.515 \\
\cline { 2 - 5 } & Educational Status & 1.237 & $0.865-1.768$ & 0.243 \\
\cline { 2 - 5 } & Age & 0.956 & $0.936-0.976$ & $<0.001$ \\
\hline \multirow{2}{*}{ Other } & Educational Status & 0.566 & $0.400-0.799$ & 0.001 \\
\cline { 2 - 5 } & Age & 1.038 & $0.966-1.114$ & 0.308 \\
\hline \multirow{2}{*}{ TS } & Educational Status & 3.279 & $1.033-10.402$ & $<0.001$ \\
\cline { 2 - 5 } & Ege & 1.091 & $1.062-1.122$ & $<0.001$ \\
\hline \multicolumn{2}{|c|}{ OR: Odds Ratio, Cl: confidence Interval, Reference category was set to RIA, Age: One year increase, Educational Status: $\geq$ High school \& < High school } \\
\hline
\end{tabular}


Table 4. Trends of women using contraceptives

\begin{tabular}{|l|c|}
\hline Method & (\%) \\
\hline Intra uterine device & 46.4 \\
\hline Condom & 19.2 \\
\hline Coitus interruptus & 16.4 \\
\hline Tubal sterilization & 11.0 \\
\hline Oral contraceptive drugs & 5.7 \\
\hline Others & 1.2 \\
\hline
\end{tabular}

In this study, the most commonly used contraceptive methods were IUD (46.4\%) and condom (19.2\%). Similar to our results, in a study conducted in another city in Turkey, the most common contraception methods were IUD and male condom with rates of $38 \%$ and $19.4 \%$ respectively (5). However, in developed countries such as Spain and Germany, the commonly preferred methods are condom and pill, respectively $(6,7)$. In Canada, Australia and France, OC is reported as the leading method $(8,9)$. The OC and female sterilization have been the two leading methods in the United States since 1982 (4). In the United States, 11-13\% of married couples were using male sterilization and $22-24 \%$ were using female sterilization. However OCD (6\%) and tubal sterilization (11\%) were the least preferred methods in our study. In the United States, 5.5\% of women were currently using IUDs. Although this rate was estimated as $46.4 \%$ in our study, the actual IUD usage rate was approximately $20 \%$ in Turkey. As a relatively new option, subcutaneus implant applications were preferred by about $1 \%$ of women in our study, similar to the worldwide preference rate.

Current use of contraception is most prevalent among women aged 30-39 and older women (aged 40-44) are less likely to use family planning than younger women (6). The rate of oral contraception usage was found to have an inverse correlation with age, and $75 \%$ of users were younger than 40 years. The rate of IUD usage was found to be $2.1 \%$ in the youngest age group and this rate increases to almost $37 \%$ among women between 30-39 years of age. Condom and oral contraceptives were preferentially used by childless women, while tubal sterilization and IUDs were most often used by women with two or more children. Meanwhile, the use of contraception is also more common after at least two or three children.

In most countries, the women with higher educational levels were found to use one of the contraceptive methods, more than less educated women (10). As educational levels changed, the choice of contraceptive method also varied. In women with higher educational levels, IUDs, condom and coitus interruptus were used less frequently, whereas OCs and tubal sterilization were preferably used. Through the rise in educational level, people have become less fearful about the adverse effects of hormonal contraceptive methods and have realized the advantages of modern methods. In the study, there was a significant relationship between educational level and the preferred method of contraception. However, as the educational level improved, the prevalence of condom and IUD usage decreased and OCD and tubal sterilization preference rates increased.

Reasons for the injectable method preference of women were reported as their long-acting effect, lack of the concern about missing a daily pill and ease of appropriate use. We do not advise using long-acting methods in our daily practice due to their side effects such as amenorrhea, metrorraghia and menstrual irregularities. However, OC preference could be explicated by its reversibility, its plentiful efficency and convenience and the scarcity of side effects. Male condom preferring subjects explain their consideration by convenience, advantage of prevention of sexually transmitted diseases including HIV and easy accessibility of this method, whereas those preferring the implant mentioned long-lasting effects (11).

Unintended pregnancies are still a major public health issue. Thirty-seven out of every 100 live births are either undesired or unplanned and $23.6 \%$ of pregnancies result in induced abortions in Turkey (6). Although unsafe abortions are entirely preventable, they still occur in all developing regions. The major public health implications include, but are not limited to, maternal morbidity and mortality. In addition, unsafe abortions bring heavy financial costs to women and to health services for treating complications.

In conclusion, in our population, contraception usage rates were low. Thec most commonly preferred method was IUD, as a more effective way of contraception. Oral contraceptive utilization rates were even more meager. One in five women, in terms of contraception, preferred methods with high failure rates like male condoms. These results demonstrated that the rates of contraception utilization and more effective contraception methods usage need to be increased by providing better family planning systems and counselling opportunities.

\section{Conflict of interest}

No conflict of interest was declared by the authors.

\section{References}

1. Salter C, Johnston HB, Hengen N. Care for postabortion complication; Saving women's life. Population Report, Series L, No. 10. Baltimore: Johns Hopkins School of Public Health, Population Information Program, 1997.

2. Paxman J, Rizo A, Brown L, Benson J. The clandestine epidemic: the practice of unsafe abortion in Latin America. Stud Fam Plan 1993; 24: 206-14. [CrossRef]

3. Sathar ZA, Chidambaram VC. Differentials in contraceptive use. Voorburg, Netherlands: International Statistical Institute, 1984.

4. Mosher WD, Jones J. Use of contraception in the United States: 1982-2008. Vital Health Stat 23. 2010; 29: 1-44.

5. Turan JM, Bulut A, Nalbant $H$. The quality of family planning services in two low-income district of Istanbul. Turk J Popul Stud. 1997; 19: 3-24.

6. Ozalp S, Yalcin OT, Hassa H, Erbay B, Dalan N. Factors affecting the contraceptive choice in a developing country.Int $\mathrm{J}$ Gynaecol Obstet. 1999; 65: 53-7. [CrossRef]

7. Oddens BJ, Wemer HM, Visser AP, Ketting E. Contraception in Germany: a review. Adv Contracept 1993; 9: 105-6. [CrossRef]

8. Martin K, Wu Z. Contraceptive use in Canada: 1984-1995. Fam Plann Perspect 2000; 32: 65-73. [CrossRef]

9. Yusuf F, Siedlecky S. Contraceptive use in Australia: evidence from the 1995 National Health Survey. Aust N Z J Obstet Gynaecol. 1999; 39: 58-62. [CrossRef]

10. Chandra A, Martinez GM, Mosher WD, Abma JC, Jones J. Fertility, family planning, and reproductive health of U.S. women: Data from the 2002 National Survey of Family Growth. National Center for Health Statistics. Vital Health Stat 2005; 23: 1-162.

11. Weldegerima B, Denekew A. Women's knowledge, preferences, and practices of modern contraceptive methods in Woreta, Ethiopia. Res Social Adm Pharm. 2008; 4: 302-7. [CrossRef] 